\title{
DEVELOPING AN INDEX OF SUSTAINABLE COLDWATER STREAMS USING FISH COMMUNITY ATTRIBUTES IN RIVER PHILIP, NOVA SCOTIA
}

\author{
YOICHIRO KANNO ${ }^{*}$ and JOHN LELAND MACMILLAN ${ }^{2}$ \\ ${ }^{1}$ School for Resource and Environmental Studies, Dalhousie University \\ Halifax, Nova Scotia B3H 3/5 \\ ${ }^{2}$ Inland Fisheries Division, Nova Scotia Department of Agriculture and Fisheries \\ Pictou, Nova Scotia BOK $1 \mathrm{HO}$ \\ ${ }^{*}$ Current address: Embassy of Japan, Ottawa, Ontario K1N 9E6
}

\begin{abstract}
An Index of Sustainable Coldwater Streams (ISCS) was developed to quantify fish community changes affected by water temperature and physical habitat quality for small streams in the River Philip Watershed, Nova Scotia. The ISCS was modified from an Index of Biotic Integrity (IBI) and intended for assessing the quality of streams as coldwater habitats. The calibration of the ISCS was thought useful since global warming and habitat degradation, two major aquatic threats in the coming era, could significantly reduce the amount of undisturbed coldwater streams in Nova Scotia; thus, a tool was necessary to identify fish species vulnerable to these threats and to monitor fish community changes in relation to water temperature and physical habitat quality. There was a strong negative correlation between water temperature and physical habitat quality, and water temperature increase and habitat degradation replaced coldwater fish assemblages dominated by salmonids with warmwater and/or tolerant fish assemblages, coupled with increased total species richness. The proposed ISCS is composed of five metrics: (1) number of fish species, (2) percent of individuals that are salmonids, (3) percent of individuals that are brook trout (Salvelinus fontinalis), (4) percent of individuals that are white sucker (Catostomus commersoni), and (5) percent of individuals that are catchable salmonids (age 2 years and older). The ISCS is a promising index to identify priority conservation areas and to monitor changes in aquatic environments.
\end{abstract}

Dans le but de quantifier les changements dans les communautés de poissons touchées par la température de l'eau et la qualité de l'habitat physique pour les petits cours d'eau du bassin hydrographique de la rivière Philip, en Nouvelle-Écosse, on a élaboré un indice de qualité des petits cours d'eau comme habitats d'eaux froides (Index of Sustainable Coldwater Streams, ISCS). Cet indice, inspiré d'un indice de l'intégrité biotique (Karr, 1981; Lyons et al., 1996), vise à évaluer la qualité des ruisseaux en tant qu'habitats d'eaux froides. On a pensé qu'il serait utile de calibrer I'ISCS, compte tenu du réchauffement de la planète et de la dégradation de l'habitat, deux menaces importantes pour les milieux aquatiques qui pourraient réduire considérablement le nombre de ruisseaux d'eaux froides non perturbés en Nouvelle-Écosse; c'est pourquoi il fallait un outil pour identifier les espèces de poissons vulnérables à ces menaces et pour surveiller les changements dans les communautés de poissons en rapport avec la température de l'eau et la qualité de l'habitat physique. On a observé une forte corrélation négative entre la température de l'eau et la qualité de l'habitat physique; de plus, l'augmentation de la température de l'eau et la dégradation de l'habitat avaient pour effet le remplacement d'assemblages de poissons d'eaux froides dominés par les salmonidés par des assemblages de poissons d'eaux tièdes ou tolérants avec une augmentation de la richesse totale en espèces. L'ISCS proposé comprend cinq paramètres : 1) le nombre d'espèces de poissons; 2) le pourcentage d'individus qui sont des salmonidés; 3) le pourcentage d'individus qui sont des ombles de fontaine (Salvelinus fontinalis); 4) le pourcentage d'individus qui sont des meuniers noirs (Catostomus commersoni) et 5) le pourcentage d'individus qui sont des salmonidés exploitables (âgés d'au moins deux ans). L'ISCS est un indice prometteur pour l'établissement de zones de conservation prioritaires et la surveillance des changements dans les milieux aquatiques.

\section{Introduction}

Human activities have caused severe loss of biodiversity in temperate freshwater fish (Miller et al. 1989, Moyle \& Leidy 1992). Among various threats to aquatic fauna in North America, habitat destruction/degradation is widely regarded as the primary

* Author to whom correspondence should be addressed 
cause (Allan \& Flecker 1993), and will likely be so in the future in light of the expected human population increase. In addition, global warming will greatly affect the distribution and survival of freshwater fish (Eaton \& Scheller 1996, Keleher \& Rahel 1996).

Considering the potential negative effects of habitat destruction and global warming, it is fair to predict that current unimpaired coldwater habitats will diminish to a great extent in North America, and thus, fish species that rely on these habitats (i.e., intolerant coldwater species) will have higher risks of extirpation and extinction. The loss of coldwater resources will be a matter of great ecological, economic, and cultural concern to regions like Nova Scotia, where recreational and subsistence fisheries of coldwater fishes (i.e., salmonids) have long been enjoyed. Characterizing fish community changes in relation to physical habitat quality and water temperature would enable us to identify fish species vulnerable to habitat destruction and global warming, and to assess and monitor the state of the aquatic environment.

In this paper, we developed an Index of Sustainable Coldwater Streams (ISCS) for small headwater streams in the River Philip Watershed, Nova Scotia. The ISCS is a multi-metric index composed of fish community attributes and is modified from an Index of Biotic Integrity (IBI) (Karr 1981, Lyons et al. 1996). The objective of the ISCS calibration was to characterize fish community changes in response to habitat degradation and water temperature increase.

\section{Materials: River Philip}

River Philip, located in Cumberland County $\left(45\left(50^{\prime} \mathrm{N}, 65\left(40^{\prime} \mathrm{W}\right)\right.\right.$, flows northeast into Northumberland Strait. Its drainage area is $699 \mathrm{~km}^{2}$ with $0.25 \%$ and $0.10 \%$ being lakes and swamps, respectively (Harger 1974). River Philip extends about $34 \mathrm{~km}$ upstream from the head of tide at Oxford (Figure 1) (Harger 1974). The average July air temperature is $18^{\circ} \mathrm{C}$, and the average January air temperature is $-7^{\circ} \mathrm{C}$; average total annual precipitation and snowfall are $1200-1400 \mathrm{~mm}$ and $250-350 \mathrm{~mm}$, respectively (Davis \& Browne 1996). Running through hilly and rural landscapes underlain by fine red sandstones, River Philip suffers relatively little from pollution (Harger 1974) and acid rain (Davis \& Browne 1996).

The drainage area harbors wild populations of native salmonids (i.e., Atlantic salmon Salmo salar and brook trout Salvelinus fontinalis) and non-native brown trout Salmo trutta (DFO 1999, MacMillan \& LeBlanc 2002). The study river today meets conservation requirements for Atlantic salmon set by the Department of Fisheries and Oceans (DFO), such as the number of returning adults (DFO 1999). The Northumberland Strait rivers are exceptional in that annual returns and escapements of Atlantic salmon have been generally unchanged since 1984, while all other areas in the province have seen moderate to significant declines in salmon during the period (DFO 1999). Cumberland County is also known to support the highest species richness of freshwater fish in Nova Scotia (Gilhen 1974). Several provincially rare minnows (e.g., blacknose dace Rhinichthys atratulus and pearl dace Semotilus margarita) are reported from the County, although none is federally rare or at risk. 


\section{Methods}

\section{Data Collection}

Two sets of electrofishing survey data were used to develop the ISCS in River Philip. A set of data was collected through an electrofishing survey on July 30 and July 31 , 2001 (termed "base survey" hereafter). The summer low-flow period was selected because it maximized sampling efficiency and reduced danger for samplers (USEPA 1997). Through preliminary field trips, 10 sites had been selected for sampling (Fig 1).

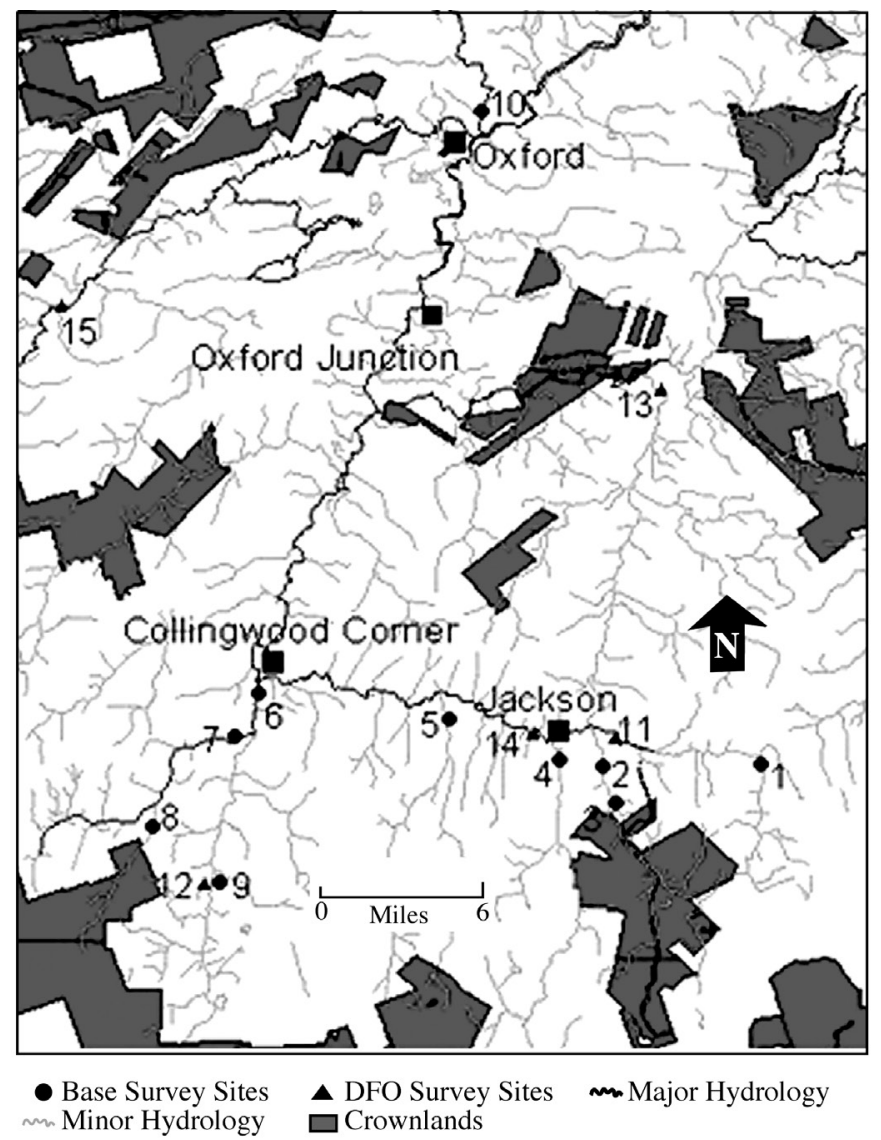

Figure 1 Survey sites in River Philip (map from Nova Scotia Geomatics Centre, Amherst, NS).

These sites were similarly small in size, and stream orders ranged between 1 and 3 on a 1:50,000 topographic map (Table 1). These streams were different in natural features and the levels of anthropogenic disturbances. In general, forested and hilly headwater areas, south of Collingwood Corner, are the least impacted portions of the watershed (Fig 1). Moving northward in a downstream direction, shorter trees and grasses start to predominate the landscape and the intensity of human activities also increases. Urbanization is evident near the town of Oxford, and site 10 is apparently the most impacted site in the base survey (Fig 1). Despite the noticeable differences among the 
10 sites in the base survey, all the sites would be expected to be capable of supporting coldwater fish communities in the absence of human activities, although upstream portions in the watershed are probably more suitable coldwater sites than downstream areas due to their naturally colder water temperature.

Table 1 Selected physical characteristics of the 10 sites in the base survey.

\begin{tabular}{lllllllllll}
\hline & Site 1 & Site 2 & Site 3 & Site 4 & Site 5 & Site 6 & Site 7 & Site 8 & Site 9 & Site 10 \\
\hline Sampled length & $60 \mathrm{~m}$ & $60 \mathrm{~m}$ & $50 \mathrm{~m}$ & $50 \mathrm{~m}$ & $50 \mathrm{~m}$ & $60 \mathrm{~m}$ & $70 \mathrm{~m}$ & $50 \mathrm{~m}$ & $60 \mathrm{~m}$ & $60 \mathrm{~m}$ \\
\hline Mean width & $4.1 \mathrm{~m}$ & $3.7 \mathrm{~m}$ & $6.4 \mathrm{~m}$ & $5.6 \mathrm{~m}$ & $3.7 \mathrm{~m}$ & $3.5 \mathrm{~m}$ & $4.1 \mathrm{~m}$ & $6.4 \mathrm{~m}$ & $4.5 \mathrm{~m}$ & $4.9 \mathrm{~m}$ \\
\hline Mean depth & $14 \mathrm{~cm}$ & $20 \mathrm{~cm}$ & $41 \mathrm{~cm}$ & $17 \mathrm{~cm}$ & $11 \mathrm{~cm}$ & $14 \mathrm{~cm}$ & $19 \mathrm{~cm}$ & $21 \mathrm{~cm}$ & $27 \mathrm{~cm}$ & $21 \mathrm{~cm}$ \\
\hline Stream order & 3 & 2 & 3 & 2 & 1 & 2 & 2 & 2 & 3 & 3 \\
\hline
\end{tabular}

At each site of the base survey, a stream reach section of 50-70m in length was sampled using a Smith-Root incorporated model-12 backpack electrofisher. Each stream section had several riffle-pool sequences, and a single upstream pass was made without the use of barrier nets in order to obtain a representative sample of the fish community. Fish individuals captured were identified to the species level and counted in the field, and were then released to the stream alive; several minnow individuals were brought to the laboratory for identification. For the three salmonid species encountered in the base survey (i.e., brook trout, brown trout, and Atlantic salmon), the age of each individual was estimated based on the approximate body length, which was empirically determined from scales collected from salmonid populations located in tributaries of the Northumberland Strait (MacMillan, 2001). Although some overlap does exist between body lengths of different age groups, age $0+$ was assigned to individuals with the fork length (FL) of less than $7 \mathrm{~cm}$, and age $0+$ individuals were assumed to have hatched in spring of the survey year (2001). Age 1+ was assigned to those between $7 \mathrm{~cm}$ and $12 \mathrm{~cm}$ in $\mathrm{FL}$, which were assumed to have hatched in spring of the previous year (2000). Individuals over $12 \mathrm{~cm}$ in $\mathrm{FL}$ were given age $>2+$, and their hatching was assumed to have occurred in spring of 1999 or earlier. Following the electrofishing survey, water temperature was measured from the main stream flow, read to the closest $1^{\circ} \mathrm{C}$.

Another set of fish survey data was provided by the Diadromous Fish Division of DFO (termed "DFO survey" hereafter). The DFO survey contained five sites within the study watershed (Fig 1). Its sampling period ranged from 1980 to 2000, although fish were not sampled every year during the period. One site in the DFO survey (site 12) was identical to site 9 of the base survey. Since the base survey and DFO survey employed a similar electrofishing method, results of the two surveys were considered to be comparable. Like the base survey, the DFO survey identified salmonids to species level and classified them into three age groups (i.e., age $0+, 1+$, and $>2+$ ); however, minnows were often grouped as dace spp. and the exact species composition of minnows was unknown. Therefore, minnows were assembled into one group in later analysis. Water temperature data were also included in the DFO survey result. In general, the DFO survey sampled slightly wider streams than the base survey (Table 2). 
Table 2 Stream sizes of the five DFO survey sites. Note that data were taken on August 11, 1986 for site 11; on August 2, 2002 for site 12; on August 8, 1980 for site 13; and on August 12, 1986 for site 14. No records were available for site 15.

\begin{tabular}{llllll}
\hline & Site 11 & Site 12 & Site 13 & Site 14 & Site 15 \\
\hline Mean width & $8.4 \mathrm{~m}$ & $4.5 \mathrm{~m}$ & $8.2 \mathrm{~m}$ & $9.5 \mathrm{~m}$ & N/A \\
\hline Mean depth & $17 \mathrm{~cm}$ & $27 \mathrm{~cm}$ & $38 \mathrm{~cm}$ & $22 \mathrm{~cm}$ & N/A \\
\hline Stream order & 2 & 3 & 3 & 4 & 3 \\
\hline
\end{tabular}

Physical habitat quality was visually assessed at all ten base survey sites and at all five DFO sites, using a Habitat Assessment Field Data Sheet (high gradient streams) (USEPA 1997). The Habitat Assessment Field Data Sheet is composed of 10 habitat variables, including (1) epifaunal substrate/available cover, (2) embeddedness, (3) velocity/depth regime, (4) sediment deposition, (5) channel flow status, (6) channel alteration, (7) frequency of riffles (bends), (8) bank stability, (9) vegetative protection, and (10) riparian vegetative zone width. Each habitat variable scoring ranges from 0 (lowest habitat value) to 20 (highest habitat value). The total habitat score of a site is a sum of the 10 habitat variable scores, thus ranging from 0 (lowest habitat value) to 200 (highest habitat value). It is previously shown that natural streams provide more diverse habitats that can support native biological assemblages, and human activities typically degrade natural habitat structures and native biological communities (USEPA 1997). As such, this type of physical habitat assessment can generally assess levels of physical human disturbances.

Ecological information on fish species required to develop the ISCS (i.e., origin, general tolerance, feeding guild, habitat preference, thermal categories, and spawning types) was primarily derived from Jennings et al. (1998), Halliwell et al. (1998), and Smogor \& Angermeier (1998). However, although Halliwell et al. (1998) classified all the three salmonid species found in River Philip (brook trout, brown trout, and Atlantic salmon) as "intolerant" species, we assigned "intermediate tolerance" to brown trout, considering their known tolerance of habitat degradation (Waters 1983, MacMillan \& LeBlanc 2002).

\section{Data Analysis}

The ISCS was developed to value fish communities inhabiting the most unimpaired and/or the coldest streams. This premise is thought important due to the following conservation perspective. In Nova Scotia, most coldwater species, mainly the family Salmonidae, are intolerant of habitat alteration and chemical pollution, while many cool- to warm-water species, the family Cyprinidae for example, are relatively tolerant (Kanno 2002). In addition, due to their requirements for cold water temperatures, coldwater species are generally more vulnerable to global warming than warmwater species (Eaton \& Scheller 1996, Keleher \& Rahel 1996). So, it is fair to argue that habitat degradation and global warming would impact coldwater fish more severely than warmwater species in the province. Thus, we intended to develop the ISCS in order to assess the sustainability of coldwater streams by using the coldest and minimally impacted sites as the reference condition, and by examining the changes in fish communities as related to increasing water temperature and decreasing overall habitat quality. In this regard, the purpose of an ISCS is different from that of an IBI, which is applied to streams in a homogeneous landscape to assess biological integrity of aquatic environments (Karr 1981). Nor does the ISCS aim to assess the productivity of waters. 
The calibration of the ISCS was done with a two-dimensional graphical method (Karr \& Chu 1999). In this approach, qualitative values of coldwater stream quality are placed on one axis while values of each ISCS attribute tested are placed on the other axis, and the relationship between coldwater stream quality and ISCS attributes are examined visually. Therefore, this method required that sample sites first be classified into several categories of coldwater stream quality, and that appropriate ISCS metrics be selected for test.

All base survey sites and DFO survey sites were classified into three discretionary categories of coldwater stream quality based on total habitat scores calculated with the Habitat Assessment Field Data Sheet and water temperatures: 1) excellent coldwater habitats, 2) good coldwater habitats, and 3) poor coldwater habitats. Excellent coldwater habitats were defined as those having total habitat scores over 150 and water temperatures below $16^{\circ} \mathrm{C}$. Good coldwater habitats failed to meet at least one of the qualifications for excellent habitats, but still possessed habitat scores over 110 and summer water temperatures below $20^{\circ} \mathrm{C}$. Brook trout, the most vulnerable species to high water temperatures in River Philip (MacMillan \& LeBlanc 2002), tend to avoid water temperatures above $20^{\circ} \mathrm{C}$ (MacMillan et al. 2004); so, waters less than $20^{\circ} \mathrm{C}$ are currently considered to be high-quality coldwater streams. However, we used a cut-off point of $16^{\circ} \mathrm{C}$ to separate excellent coldwater streams from good coldwater streams in order to account for the projected $4^{\circ} \mathrm{C}$ increase in water temperature in a century for the province due to global warming (Hengeveld 2000). Thus, excellent coldwater streams might still function as such after effects of global warming become prominent, while good coldwater streams are likely to become uninhabitable for brook trout, and thus less sustainable as coldwater streams. Streams with habitat scores below 110 or with summer water temperatures above $20^{\circ} \mathrm{C}$, or both, were classified as poor coldwater habitats.

Originally, eighteen candidate ISCS metrics were compiled from the literature, and were thought testable in the study area (Miller et al. 1988, Mundahl \& Simon 1998) (Table 3). However, only 10 of these metrics turned out to be so after the completion of data collection, due to lack of data and rarity of species on which metrics are based. So, the remaining 10 metrics were considered for further analysis.

With a two-dimensional graph, each of the 10 metrics was examined to detect whether the metric varied systematically across a gradient in the quality of coldwater habitats. Systematic changes were either constant changes along the entire gradient of coldwater quality (shown as "linear" distributions on a graph), or those that showed sudden responses in limited ranges of coldwater quality (shown as "skewed" distributions on a graph) (Karr \& Chu 1999). Those metrics that showed systematic changes were then examined for redundancies because a metric that is highly correlated to another metric adds little new information (Karr et al. 1986, Kerans \& Karr 1994, Mundahl \& Simon 1998). Following Mundahl \& Simon (1998), all possible combinations of two metrics were correlated with each other. If the Pearson correlation coefficient was 0.85 or greater in absolute values, the metric that showed less systematic changes on a graph was eliminated. The ISCS was composed of all metrics that cleared the above criteria.

Scoring thresholds of each metric included in the ISCS were also derived using a graphical method. On a graph, metric values were plotted in a rank order, and their "natural shifts and breaks" were carefully examined for cut-off points (Karr \& Chu 1999). Metric values were then trisected with discretion, and we assigned scores of 10 , 5 , and 0 according to whether they approximate, deviate somewhat from, or deviate strongly from the values expected at the reference sites. Where applicable, the scoring 
Table 3 Eighteen ISCS metrics that were originally considered to be testable in River Philip and their predicted response to environmental degradation (compiled from Miller et al. (1988) and Mundahl \& Simon (1998)). Ten metrics with asterisk $\left(^{*}\right)$ were actually tested for the inclusion in the final ISCS.

\begin{tabular}{ll}
\hline Metrics & $\begin{array}{l}\text { Predicted } \\
\text { Response }\end{array}$ \\
\hline $\begin{array}{l}\text { Species richness and composition } \\
\text { Number of fish species* }\end{array}$ & $\begin{array}{l}\text { Increase } \\
\text { Number of coldwater species* }\end{array}$ \\
Number of benthic species & Decrease \\
Number of water column species & Variable \\
Percent of individuals that are coldwater species & Decrease \\
Indicator species & \\
Number of intolerant species* & Decrease \\
Number of tolerant species & Increase \\
Percent of individuals that are intolerant* & Decrease \\
Percent of individuals that are tolerant & Increase \\
Percent of individuals that are salmonids* & Decrease \\
Percent of individuals that are brook trout* & Decrease \\
Percent of individual salmonids that are brook trout* & Decrease \\
Percent of individuals that are white sucker* & Increase \\
Trophic function & \\
Percent of individuals that are generalist feeders* & Increase \\
Percent of individuals that are insectivores & Decrease \\
Percent of individuals that are top carnivores & Decrease \\
Percent of individuals that are catchable salmonids (age $>2+)^{*}$ & Decrease \\
Reproductive function & \\
Percent of individuals that are simple lithophilic spawners & Decrease \\
\hline
\end{tabular}

criteria were set rather conservatively by making the range of the high value (10) proportionately smaller than its equal trisection, taking into account the fact that truly pristine areas do not exist and thus high values of 10 should be given to a relatively small number of sites.

The total ISCS score for each site was calculated by adding all metric scores. Based on the final ISCS scores of all sites, we developed narrative interpretations of sustainability as coldwater streams for five classes (excellent, good, fair, poor and very poor), by adapting those developed by Lyons et al. (1996) and Mundahl \& Simon (1998).

\section{Results}

\section{Fish Surveys}

The two fish surveys contained, not surprisingly, similar species richness and relative abundance. In the base survey, a total of 735 individuals of 12 species were recorded from the 10 sites. Three salmonid species (i.e., brook trout, brown trout, and Atlantic salmon) accounted for 607 individuals $(82.6 \%)$, with brown trout being the most common species in the base survey (280 individuals, 38.1\%). In general, eight headwater sites (site 2 to site 9) were inhabited almost entirely by these three salmonids, and thus the species richness was low. The remaining one headwater site (site 1) also harbored the three salmonids while containing a fairly high proportion of blacknose 
dace $(44.0 \%)$. Site 10 was exceptional in that it possessed a completely different fish assemblage. Ten species were found in this site and many of them were tolerant and/ or cool- to warm-water species (e.g., white sucker Catostomus commersoni, common shiner Luxilus cornutus and blacknose dace), and brook trout and brown trout were absent. In general, sites 1-9 seemed to possess suitable abiotic conditions as coldwater streams on the basis of water temperatures and habitat quality; water temperatures ranged from $11^{\circ} \mathrm{C}$ to $17^{\circ} \mathrm{C}$, and habitat scores were between 178 and 115 for these headwater sites. In contrast, site 10 had a much higher water temperature $\left(24^{\circ} \mathrm{C}\right)$, and the habitat score was lowest (95).

The DFO survey recorded 8 species and one group of fish assembled as dace spp. Similar to the base survey, three salmonid species were predominant among the fish individuals captured (87.0\%). However, the most abundant salmonid species in the DFO survey was Atlantic salmon (1053 individuals, 52.7\%), followed by brown trout (535 individuals, $26.8 \%$ ) and brook trout (150 individuals, $7.5 \%$ ). This is probably because the DFO survey generally focused on wider streams than the base survey, and Atlantic salmon tends to inhabit wider and/or warmer streams than trout (Eaton et al. 1995, Bardonnet \& Baglinière 2000). Judging from the base survey results and local knowledge, dace spp. should be one of the following species: blacknose dace, common shiner, golden shiner Notemigonus crysoleucas, creek chub Semotilus atromaculatus, lake chub Couesius plumbeus, or blacknose shiner Notropis heterolepis. All the species identified in the DFO survey, except sea lamprey, were also recorded in the base survey. Therefore, a total of 13 species was recorded in the two surveys (Appendix 1). The predominance of salmonids in both surveys indicates that the study area generally provides suitable habitats for coldwater species.

\section{Development of the Index of Sustainable Coldwater Streams (ISCS)}

The development of the ISCS helped to understand fish community changes in relation to water temperature and physical habitat quality. There was a significant negative correlation between water temperature and overall habitat quality (Pearson correlation $r=-0.677$, $p$-value $=0.006$ ); this was consistent with a field observation that naturally colder upstream sites were less disturbed and possessed better physical habitat quality than warmer downstream reaches.

Of the ten metrics assessed for the ISCS inclusion (refer to Table 3), the graphical analysis indicated that two metrics did not respond to a gradient of coldwater habitat quality (number of intolerant species, percent of individuals that are intolerant) (Fig 2 and 3). These two metrics showed no distinct patterns on the graphs. Another metric showed a general, but biologically insignificant responses (number of coldwater species) (Fig 4). The number of coldwater species was generally higher in high-quality coldwater streams; however, the discrepancies were less drastic than the following seven metrics that showed systematic changes.

Seven metrics demonstrated systematic changes with the quality of coldwater streams (Fig 5-11). Two of them showed linear responses across the entire gradient of the quality of coldwater streams (number of fish, and percent individuals that are catchable salmonids) (Fig 5-6), indicating that these metrics have a wide range of sensitivity. This means that, as the quality of coldwater streams decreased, the number of fish species increased throughout and the percent of catchable salmonids individuals showed a constant decrease. The other five metrics showed skewed distributions of metric values (Fig 7-11), indicating the limited ranges where these metrics were most capable of distinguishing stream qualities. Three of them were reliable discriminators between poor coldwater streams and good coldwater streams (percent of individuals that are salmonids, percent of individuals that are white sucker, and percent of 
Fig 2-11 Responses of 10 metrics tested for the ISCS inclusion. All base survey sites and DFO survey sites (including multi-year samples) were pooled for the analysis. When more than one sites share the same value on the graphs, points were slightly moved from their exact locations for better graphical presentation.

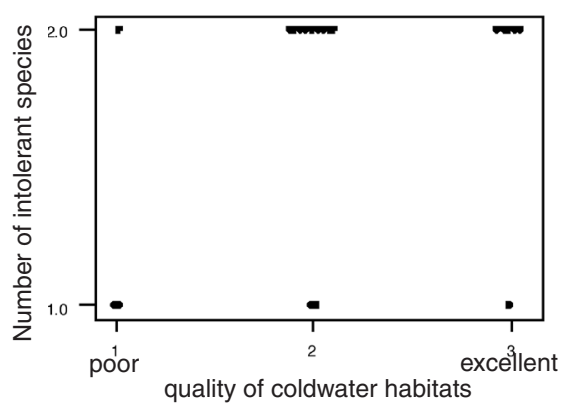

Fig 2 \# intolerant species

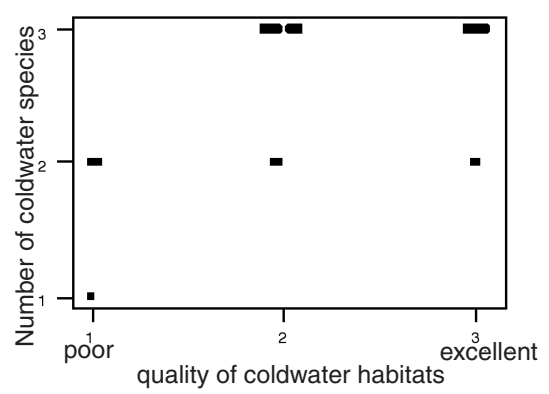

Fig 4 \# coldwater species

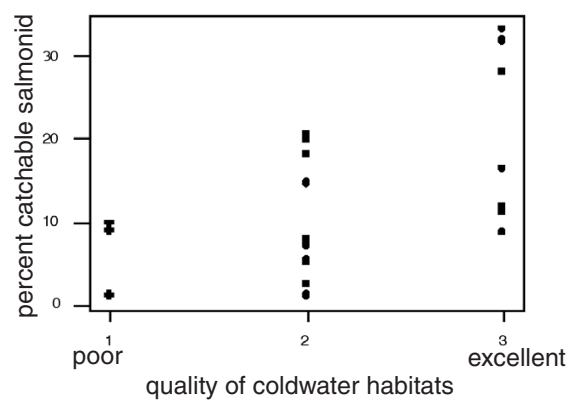

Fig $6 \%$ catchable salmonid

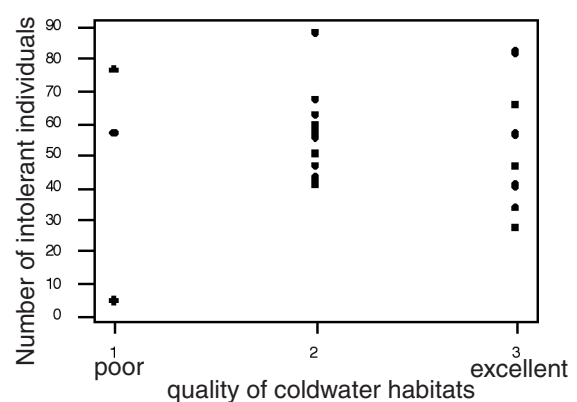

Fig $3 \%$ intolerant species

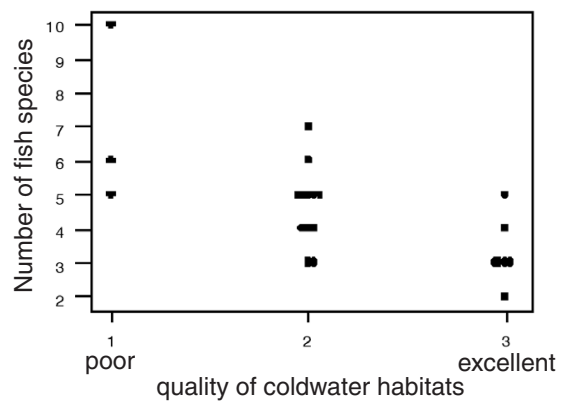

Fig 5 \# fish species

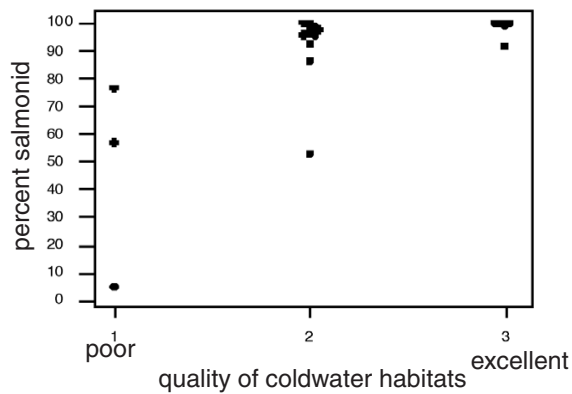

Fig $7 \%$ salmonid 


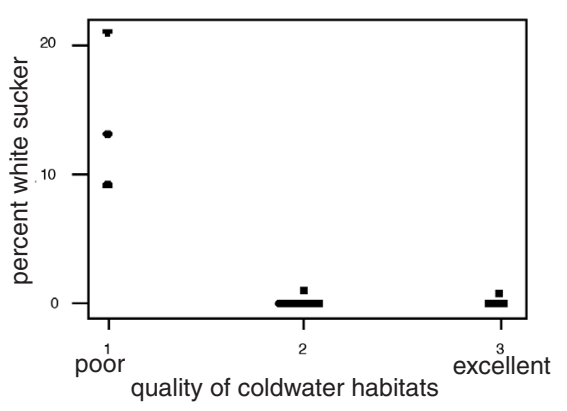

Fig $8 \%$ white sucker

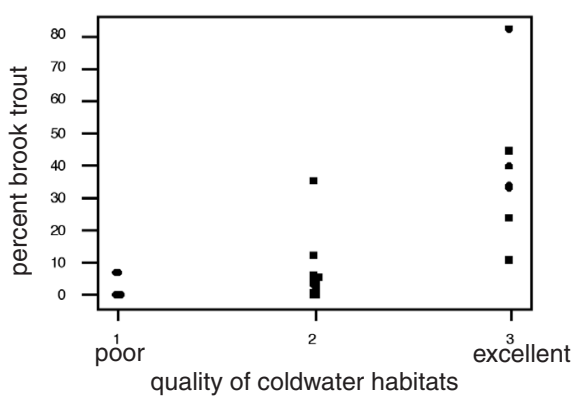

Fig $10 \%$ brook trout

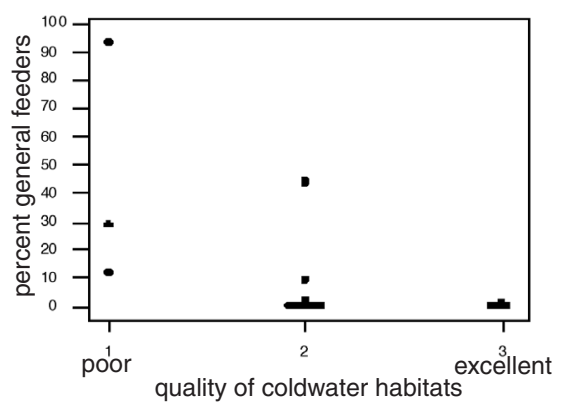

Fig $9 \%$ general feeders

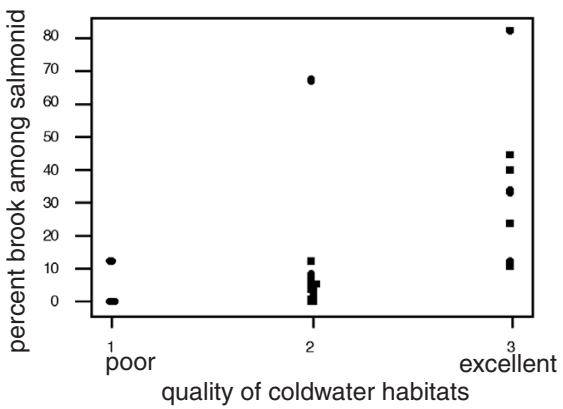

Fig $\mathbf{1 1} \%$ brook trout among salmonids

individuals that are general feeders) (Fig 7-9). For example, the percentage of salmonid individuals (Fig 7) was relatively similar along the higher end of the coldwater quality, but sharply declined in poor coldwater streams. Finally, the last two metrics were most capable of distinguishing excellent coldwater habitats from good coldwater habitats (percent of individuals that are brook trout, and percent of individual salmonids that are brook trout) (Fig 10-11).

These seven metrics that showed systematic changes to the quality of coldwater habitats were correlated with each other. Two pairs of metrics demonstrated strong correlation (Pearson's correlation $r>0.85$ ) (percent of individuals that are salmonids and percent of individuals that are general feeders; percent of individuals that are brook trout and percent of individual salmonids that are brook trout). So the metric in each pair that showed less systematic changes in the graphical analysis (refer to Fig 2-11) was eliminated, including percent of individuals that are general feeders and percent of individual salmonids that are brook trout.

As a result, the following five metrics were selected for the ISCS in River Philip:

(1) Number of fish species

(2) Percent of individuals that are salmonids

(3) Percent of individuals that are brook trout

(4) Percent of individuals that are white sucker

(5) Percent of individuals that are catchable salmonids (age $>2+$ ) 
On a graph, these five metrics were visually tested for scoring criteria, and values of each metric were subjectively trisected (Figures 12-16). Due to the trisection method, each metric had a maximum score of 10 , a middle score of 5 , and a minimum score of 0 (Table 4). Thus, the total ISCS values ranged from 50 (the possible highest value) to 0 (the possible lowest value).

Fig 12-16 Scoring criteria for the 5 metrics included in a River Philip-ISCS. All base survey sites and DFO survey sites (including multi-year samples) were pooled for the analysis.

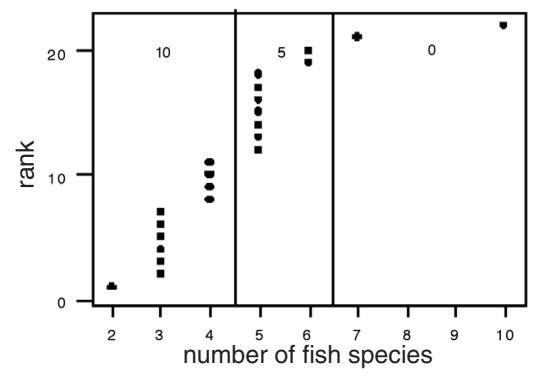

Fig 12 \# fish species

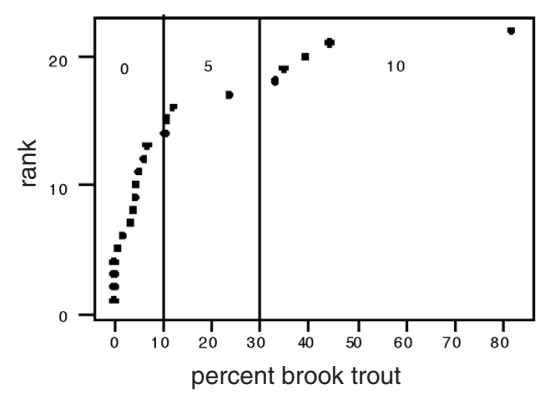

Fig $14 \%$ brook trout

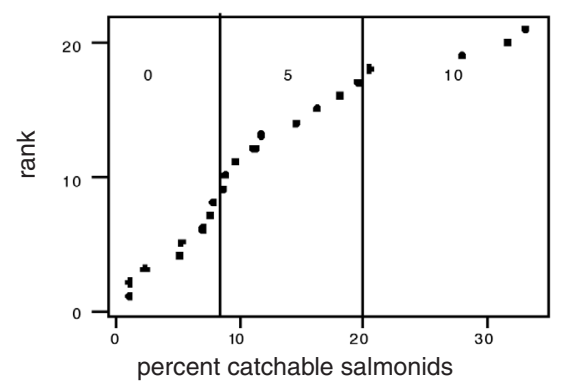

Fig $16 \%$ catchable salmonids

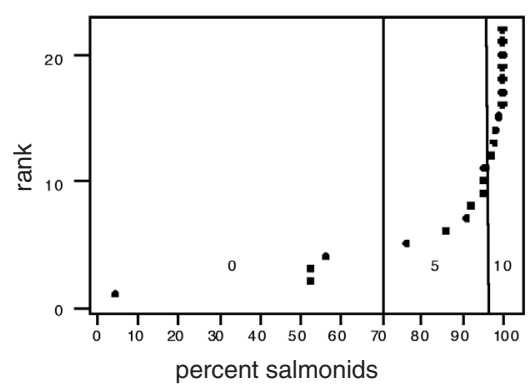

Fig $\mathbf{1 3} \%$ salmonids

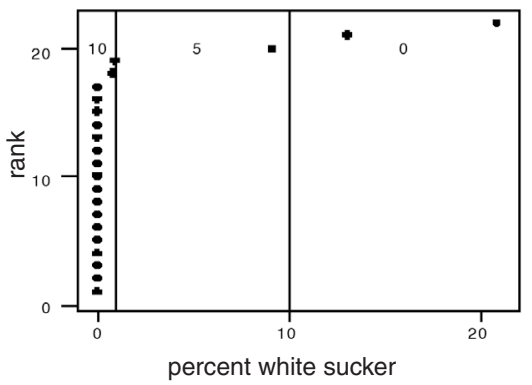

Fig $15 \%$ white sucker 
Table 4 Scoring criteria for the 5 metrics included in an ISCS for River Philip.

\begin{tabular}{lccc}
\hline & \multicolumn{3}{c}{ Scoring } \\
\cline { 2 - 4 } Metrics & $\mathbf{0}$ & $\mathbf{5}$ & $\mathbf{1 0}$ \\
(poor) & (good) & (excellent) \\
(1) Number of fish species (\# species) & $>6$ & $5-6$ & $<5$ \\
(2) Percent of individuals that are salmonids (\% salmo) & $<70$ & $70-96$ & $>96$ \\
(3) Percent of individuals that are brook trout (\% brook) & $<10$ & $10-30$ & $>30$ \\
(4) Percent of individuals that are white sucker (\% sucker) & $>10$ & $1-10$ & $<1$ \\
(5) Percent of individuals that are catchable salmonids (\% CS) & $<8$ & $8-20$ & $>20$ \\
\hline
\end{tabular}

Using the criteria retained (Table 4), the total ISCS value was calculated for all sites in the base survey and the DFO survey (Appendix 2). Based on these total ISCS values, narrative criteria for interpreting ISCS scores were also determined ranging through 5 classes from excellent (ISCS scores: 50-45) to very poor (ISCS scores: 5-0) (Table 5). In general, uppermost headwater sites had higher scores, but not always. For example, site 1, although an uppermost headwater site, had a "fair" condition. For several DFO sites that had multi-year samples, the variability between years was relatively small. For example, site 11 was sampled for six years, during which the ISCS scores ranged relatively subtly between 30 (good) and 20 (fair). The largest ISCS variability between years was detected for site 12, which had an ISCS score of 30 (good) in 1999, and 45 (excellent) in 1995.

\section{Discussion}

\section{Fish Community Characteristics in Coldwater Streams in River Philip}

Our data and analyses documented fish community composition in coldwater streams in River Philip, and its changes with increasing water temperature and decreasing physical habitat quality. High-quality coldwater streams in the research area were almost entirely dominated by three salmonid species including brook trout, brown trout, and Atlantic salmon. Coolwater and warmwater species were typically absent or present in very limited numbers in these streams. These characteristics make coldwater fish assemblages in River Philip simpler than those reported from other regions of North America, which typically harbor "one or a few salmonids, one to three sculpin species, perhaps a stickleback, and a few cyprinids or catastomids" (Lyons et al. 1996, p 250). With a relatively small number of fish species having colonized Nova Scotia since the last glaciation, the province has a reduced number of fish species and lies outside the distributional range of sculpins, a major group of fish present in many other coldwater streams in North America (Gilhen 1974, Scott \& Crossman 1973).

With increasing water temperature and decreasing overall habitat quality, coldwater fish communities dominated by salmonids were gradually replaced with cool- to warm-water fish assemblages that are mainly composed of tolerant species. Warmer and/or more degraded sites in our study were inhabited by minnows such as blacknose dace and creek chub, and white sucker. The species richness in these sites was much higher than that of high-quality coldwater streams. These results were consistent with other studies that had reported modifications of coldwater fish assemblages due to environmental degradation (Lyons et al. 1996, Mundahl \& Simon 1998).

Between the two habitat variables measured, it was difficult to determine which variable has a stronger effect on fish community changes because the two variables were highly correlated to each other. Possibly, both water temperature and physical 
Table 5 Rating categories for ISCS scores and fish community characteristics for each category (adapted from Lyons et al. 1996, Mundahl \& Simon 1998).

\begin{tabular}{|c|c|c|}
\hline Total ISCS Score & Rating & Fish Community Characteristics \\
\hline $50-45$ & Excellent & $\begin{array}{l}\text { Comparable to the best coldwater streams in the region; fish } \\
\text { communities are dominated almost entirely by salmonids; } \\
\text { although exotic brown trout are typically present, brook trout } \\
\text { account for a good proportion of total individuals ( }>30 \% \text {; } \\
\text { Atlantic salmon are usually present; large and catchable } \\
\text { salmonids are common; coolwater sea lamprey and } 3 \text {-spine } \\
\text { stickleback may be found in limited numbers; minnows and } \\
\text { white sucker are absent. }\end{array}$ \\
\hline $40-30$ & Good & $\begin{array}{l}\text { Some impairment present; salmonids are still a predominant } \\
\text { fish group, but the composition is somewhat different; while } \\
\text { brook trout and large salmonid individuals are reduced in } \\
\text { abundance, brown trout and Atlantic salmon are found } \\
\text { more commonly; sea lamprey and } 3 \text {-spine stickleback are } \\
\text { still limited in abundance; minnows and white sucker are } \\
\text { usually absent. }\end{array}$ \\
\hline $25-20$ & Fair & $\begin{array}{l}\text { Moderate impairment; the proportion of salmonid individuals } \\
\text { is reduced; brook trout are rare or absent; large individuals } \\
\text { of salmonids are less common; coolwater species (e.g., sea } \\
\text { lamprey, } 3 \text {-spine stickleback, blacknose dace, and white } \\
\text { sucker) may be present in good numbers. Total species } \\
\text { richness is now slightly higher. }\end{array}$ \\
\hline $10-15$ & Poor & $\begin{array}{l}\text { Major impairment; salmonids account for only a small } \\
\text { portion of fish communities; brook trout are absent; cool } \\
\text { water species are present in good numbers; tolerant and/ } \\
\text { or warmwater species are found commonly; total species } \\
\text { richness is relatively high. }\end{array}$ \\
\hline $0-5$ & Very poor & $\begin{array}{l}\text { Have lost values as coldwater streams; salmonids are absent } \\
\text { or found in very limited numbers; various cool-to warmwater } \\
\text { species and/or tolerant species such as blacknose dace, creek } \\
\text { chub, and white sucker arefound, making the species richness } \\
\text { higher than that of high-quality coldwater streams. }\end{array}$ \\
\hline
\end{tabular}

habitat quality were important factors influencing fish community composition. Alternatively, only one of them was an influential variable, and the other variable was spurious. Further, neither of the two variables may be important, and other variables not measured here, such as stream size, elevation, and water quality, may have more influence on the observed changes in fish communities.

Similarly, there was a lack of data to test the hypothesis that environmental degradation typically raises water temperatures and makes coldwater habitats more hospitable for cool- and warm-water species (Lyons et al. 1996). That water temperatures were generally colder in minimally impacted headwater streams than in more developed downstream reaches can be explained in several ways. Downstream reaches may have been naturally warmer than the headwaters, and, thus, the changes in fish communities may have essentially been caused by natural variability of abiotic conditions (Rahel \& Hubert 1991). However, we doubt this is the dominant influence. As an alternative explanation, the natural variability may have been very small and riparian human activities may have raised water temperatures in downstream portions 
of the watershed (Lyons et al. 1996, Mundahl \& Simon 1998). Changes in fish communities could have been caused by a combination of natural and anthropogenic factors.

\section{ISCS Metric Description}

The ISCS developed for River Philip is an appropriate tool to assess and monitor the quality of coldwater streams. The ISCS derived from the study watershed was composed of the five most significant metrics that were based on species richness (number of fish species), indicator species (percent of individuals that are salmonids, percent of individuals that are brook trout, percent of individuals that are white sucker), and trophic function (percent of individuals that are catchable salmonids). The integrative nature of this type of biological assessment gives strength to the ISCS that a single-taxon indicator does not possess (Karr et al. 1986, Fausch et al. 1990).

\section{Metric 1. Species richness}

High-quality coldwater streams in North America are known to possess limited species richness, and their degradation typically leads to increased numbers of species (Lyons et al. 1996, Mundahl \& Simon 1998). The increase in species richness in degraded coldwater streams occurs because the degradation of coldwater streams increases water temperatures, and cool- to warm-water fish species typically inhabiting downstream reaches of the basin system invade the originally coldwater habitats (Lyons et al. 1996). The response of coldwater fish assemblages to environmental degradation is in sharp contrast with that of warmwater fish assemblages, where a decline in species richness usually indicates environmental degradation (Karr et al. 1986, Fausch et al. 1990). In the present ISCS, this metric showed a linear response across the entire gradient of the quality of coldwater streams. This means that the metric had a wide range of "sensitivity", thus the number of species increased constantly with transition from coldwater habitat to warmwater habitat.

\section{Metric 2. Percent of individuals that are salmonids}

Salmonids in River Philip include brook trout, brown trout, and Atlantic salmon, and they are representative members of coldwater streams in the study area; the other coldwater species in the area is lake chub, which were not frequently captured in our current study. Brook trout and Atlantic salmon are also the only two species collected in our survey that are assigned with intolerant status, and brown trout have intermediate tolerance. Thus, this metric approximates to "percent of individuals that are coldwater species" and "percent of individuals that are intolerant species". This metric showed a skewed distribution on a graphical analysis, and is a good indicator that distinguished good coldwater streams from poor coldwater streams.

\section{Metric 3. Percent of individuals that are brook trout}

Brook trout are known to be sensitive to environmental degradation and to prefer a colder thermal range than brown trout and Atlantic salmon (Eaton et al. 1995, Taniguchi et al. 1997). These previous observations were consistent with our results in that brook trout was associated with the coldest and minimally-impacted headwater streams. This metric was a reliable indicator of excellent coldwater streams.

\section{Metric 4. Percent of individuals that are white sucker}

White sucker is a coolwater tolerant species, and is indicative of stream impairment of both warmwater (Karr et al. 1986) and coldwater streams (Mundahl \& Simon 1998). In River Philip, white sucker was absent or extremely rare in excellent and good 
coldwater streams, and became only noticeable in poor coldwater habitats. Thus, this metric successfully distinguished between poor and good coldwater streams in River Philip.

\section{Metric 5. Percent of individuals that are catchable salmonids (age $>+2$ )}

This metric was a modification from Miller et al. (1988), who used "percent of individuals that are catchable salmonids $(>15 \mathrm{~cm})^{\prime \prime}$. Similar to species richness, this metric showed a wide range of sensitivity, and thus abundance of catchable salmonids decreased constantly as the quality of coldwater streams decreased. However, this metric may be least reliable among the five metrics retained since it showed a high variability at each category of coldwater stream quality (Karr \& Chu 1999). In small streams that we surveyed, undisturbed habitats may be more likely to retain habitat complexity (e.g., sinuosity, instream cover, and undercut bank), including pockets of deep pools with which large individual salmonids were typically associated. In contrast, impacted streams possessed more homogeneous stream features, and were often straight and shallow. In some cases, the presence of dams and water diversions for agricultural use has been known to reduce the level of water flow in immediate downstream reaches, diminishing microhabitats where large salmonid individuals are often found.

\section{Ecological Properties of the ISCS and its Potential Use in Stream Management}

A multi-metric index to assess stream conditions is based on an assumption that fish communities are diverse, thus their examination provides a variety of ecological information on their ambient conditions (Karr et al. 1986, Fausch et al. 1990). For example, Halliwell et al. (1998) recommended that an IBI should be derived from fish communities containing at least four resident species. However, the ISCS stemmed from a very simple coldwater fish assemblage and, due to its simplified nature, only five metrics were retained. In comparison, the original IBI developed for warmwater streams had 12 metrics (Karr 1981) and a coldwater IBI developed by Mundahl \& Simon (1998) was also composed of 12 metrics. As the strength of a multi-parameter index is its large number of metrics, the ISCS is probably a less effective tool in biological monitoring.

This defective aspect could be overcome by adding more metrics. Due to data deficiency, some candidate metrics were not tested in our study (e.g., metrics concerning abundance and condition, and metrics that required the identification of minnows to species), and testing these metrics warrants further attention. In addition, an effective way might be to combine fish assemblages with other taxa. Probably, the best group for consideration in River Philip would be benthic invertebrates. Benthic invertebrates are an important and diverse component of coldwater biological communities (Kerans \& Karr 1994, Karr \& Chu 1999), and were also easily located by examining stream bottom substrates in our field survey.

We believe that a multi-metric index similar to the ISCS is applicable to other Northumberland Strait streams because they seem to possess a similar species richness and composition (Gilhen 1974). However, the ISCS based on fish assemblages would not be successfully developed in regions that have lower species richness, such as those areas situated at both ends of the province (Gilhen 1974). The use of macroinvertebrates is probably the best approach to inventory and assess biological conditions in these waters. 
In further testing and developing an ISCS in other regions, issues on sampling protocols should be borne in mind. First, the sampling season should be specified to allow for comparison between years. The summer low-flow season is usually recommended (USEPA 1997). Second, ISCS variability between years should be further tested. Natural variability of fish composition in headwater streams is relatively large (Danehy et al. 1998), and decisions on stream conditions should not be based on a single year survey result.

While the total ISCS score is a single numerical value, the evaluation of individual metrics can allow us to further examine biological attributes of the data in a general way and to guide us to an appropriate management plan of a given site (Karr et al. 1986). This process can be more effective if coupled with physical and chemical data (Fausch et al. 1990, Snyder et al. 1998). In the present research, for example, site 4 has an overall rating of "good" coldwater quality. A close look at individual metrics indicates that this site did not attain "excellent" status due to very low abundance of brook trout and low abundance of large salmonid individuals; in addition, the vegetative riparian zone width is relatively narrow, and the flow regime is less than ideal because of a small dam built a few kilometers upstream. The water temperature $\left(17^{\circ} \mathrm{C}\right)$ is relatively high among coldwater streams in the region. With this information available, a probable conservation management plan for this site would be to restore riparian zones and remove the upstream dam, which would be expected to restore riparian processes and in-stream physical habitats, and to lower water temperature. As another example, site 8 has a total ISCS score of 45 (excellent status) with a high habitat score (165) and a sufficiently cold water temperature $\left(13^{\circ} \mathrm{C}\right)$. This site was exceptional in that brook trout accounted for more than $80 \%$ of the fish community. In addition, this site is probably the most unimpaired site among all the survey sites. Habitat protection may therefore be a desirable management option for this site.

The ISCS is also useful in establishing goals for restoration work in a biological sense (Hughes et al. 1990, Karr \& Chu 1999). For example, a restoration plan could set an ISCS score of 40 for its biological goal, and the success of restoration work could be assessed numerically relative to this goal. An increase in ISCS scores after any restoration work would indicate its success, while no changes in ISCS scores would mean its failure.

While the ISCS is useful in stream management, solely relying on the index for management decisions may be misleading. The ISCS was developed to evaluate fish communities that are vulnerable to habitat degradation and global warming; however, other ecological traits of fish also contribute to extinction vulnerability. For example, although our study suggests that brook trout are more vulnerable to habitat degradation and global warming than Atlantic salmon in River Philip, the migratory nature of Atlantic salmon indicates larger habitat requirements than brook trout; thus, Atlantic salmon may be potentially more vulnerable than brook trout at the landscape level.

In conclusion, habitat degradation and water temperature increases replaced coldwater fish assemblages dominated by salmonids with warmwater and/or tolerant fish assemblages in River Philip. The ISCS weights fish assemblages in coldest and minimally impacted streams, and assesses sustainability as coldwater streams. There is a concern that increasing riparian development and global warming may reduce the amount of high-quality coldwater streams in many temperate regions, and the ISCS may be a useful tool to inventory and monitor ecological conditions of coldwater streams. 


\section{Acknowledgements}

We are grateful to John Gilhen and Danny Ripley for their assistance in the field. Karen Beazley and Martin Willison provided useful comments on earlier drafts. We thank Shane O'Neil for generously permitting us to use DFO field survey data. Thanks to Murray Hill, Director, and Don MacLean, Assistant Director, Inland Fisheries Division, Nova Scotia Department of Agriculture and Fisheries, for providing resources and advice toward this project. Financial assistance for this work was partly provided by the School for Resource and Environmental Studies, and Faculty of Graduate Studies, Dalhousie University. This publication is part of a Master of Environmental Studies thesis completed at Dalhousie University by the first author.

\section{References}

Allan JD, Flecker AS (1993) Biodiversity conservation in running waters. BioScience 43:32-43

Angermeier PL, Karr JR (1986) Applying an index of biotic integrity based on streamfish communities: considerations in sampling and interpretation. N Am J Fish Manag 6:418-429

Bardonnet A, Baglinière J (2000) Freshwater habitat of Atlantic salmon (Salmo salar). Can J Fish Aquat Sci 57:497-506

Danehy RL, Ringler NH, Stehman SV, Hassett JM (1998) Variability of fish densities in a small catchment. Ecol Freshw Fish 7:36-48

Davis DS, Browne S (1996) The natural history of Nova Scotia, Vol 1. Topics and habitats, $2^{\text {nd }}$ edn. Nimbus Publishing and Nova Scotia Museum, Halifax

DFO (Department of Fisheries and Oceans) (1999) Atlantic salmon Maritime Provinces overview for 1998. DFO Science Stock Status Report D-14 (1999), DFO Maritimes Region, Dartmouth, NS

Eaton JG, Scheller RM (1996) Effects of climate warming on fish thermal habitat in streams of the United States. Limnol Oceanogr 41:1109-1115

Eaton JG, McCormick JH, Goodno BE, O'Brien DG, Stefany HG, Hondzo M, Scheller RM(1995)A field information-based system for estimating fish temperature tolerances. Fisheries (Bethesda) 20:10-18

Fausch KD, Lyons J, Karr JR, Angermeier PL (1990) Fish communities as indicators of environmental degradation. Am Fish Soc Symp 8:123-144

Gilhen J (1974) The fishes of Nova Scotia's lakes and streams. Nova Scotia Museum, Halifax

Halliwell DB, Langdon RW, Daniels RA, Kurtenbach JP, Jacobson RA (1998) Classification of freshwater fish species of the northeastern United States for use in the development of indices of biological integrity, with regional applications. In: Simon TP (ed) Assessing the sustainability and biological integrity of water resources using fish communities. CRC Press, Boca Raton, FL, p 301-337

Harger D (1974) Proposal for Atlantic salmon stock characterization: River Philip. Diadromous Fish Division, Department of Fisheries and Oceans, Dartmouth, NS

Hengeveld HG (2000) Climate change digest: projections for Canada's climate future. Environment Canada, Downsview, ON

Hughes RM, Whittier RR, Rohm CM, Larsen DP (1990) A regional framework for establishing recovery criteria. Environ Manag 14:673-683

Jennings MJ, Lyons J, Emmons EE, Hatzenbeler GR, Bozek MA, Simonson TD, Beard TD Jr, Fago D (1998) Toward the development of an index of biotic integrity for 
inland lakes in Wisconsin. In: Simon TP (ed) Assessing the sustainability and biological integrity of water resources using fish communities. CRC Press, Boca Raton, FL, p 541-562

Kanno Y (2002) Fish community changes in River Philip, Nova Scotia, and an index of sustainable coldwater streams (ISCS). MES thesis, Dalhousie University, Halifax

Karr JR, Chu EW (1999) Restoring life in running waters: better biological monitoring. Island Press, Washington, DC

Karr JR, Fausch KD, Angermeier PL, Yant PR, Schlosser IJ (1986) Assessing biological integrity in running waters: a method and its rationale. Spec Publ 5, Illinois Natural History Survey, Champaign, IL

Keleher CJ, Rahel FJ (1996) Thermal limits to salmonid distributions in the Rocky Mountain region and potential habitat loss due to global warming: a geographic information system (GIS) approach. Trans Am Fish Soc 125:1-13

Kerans BL, Karr JR (1994) A benthic index of biotic integrity (B-IBI) for rivers of the Tennessee Valley. Ecol Appl 4:768-785

Lyons J, Wang L, Simonson TD (1996) Development and validation of an index of biotic integrity for coldwater streams in Wisconsin. N Am J Fish Manag 16:241-256

MacMillan JL (2001) (Inland Fisheries Div, NS Department of Agriculture and Fisheries, Pictou, NS). Unpublished data

MacMillan JL, LeBlanc JE (2002) Biological characteristics of sea-run salmonids from a spring angler creel survey on five Northumberland Strait river systems in Nova Scotia, and management implications (draft). Manuscript and Tech Rep Series, Inland Fisheries Division, Nova Scotia Department of Agriculture and Fisheries, Pictou, NS

MacMillan JL, Caissie D, LeBlanc JE, Crandlemere T (2004) Characterization of summer water temperatures for 319 selected sites in Nova Scotia. Can Tech Rep Fish Aquat Sci (in press)

Miller DL, Leonard PM, Hughes RM, Karr JR, and 10 others (1988) Regional applications of an index of biotic integrity for use in water resource management. Fisheries (Bethesda) 13:12-20

Miller RR, Williams JD, Williams JE (1989) Extinctions of North American fishes during the past century. Fisheries (Bethesda) 14:22-38

Moyle, PB, and Leidy, RA (1992) Loss of biodiversity in aquatic ecosystems: evidence from fish faunas. In: Fiedler PL, Jain SK (eds) Conservation biology: the theory and practice of nature conservation, preservation and management. Chapman \& Hall, New York, p 127-169

Mundahl ND, Simon TP (1998) Development and application of an index of biotic integrity for coldwater streams of the upper Midwestern United States. In: Simon TP (ed) Assessing the sustainability and biological integrity of water resources using fish communities. CRC Press, Boca Raton, FL, p 383-415

Rahel FJ, HubertWA (1991) Fish assemblage and habitat gradients in a Rocky MountainGreat Plains streams: biotic zonation and additive patterns of community change. Trans Am Fish Soc 120:319-332

Scott WB, Crossman EJ (1973) Freshwater fishes of Canada. Fisheries Research Board of Canada, Ottawa

Smogor RA, Angermeier PL (1998) Effects of drainage basin and anthropogenic disturbance on relations between stream size and IBI metrics in Virginia. In: Simon TP (ed) Assessing the sustainability and biological integrity of water resources using fish communities. CRC Press, Boca Raton, FL, p 249-272 
USEPA (United States Environmental Protection Agency) (1997) Revision to rapid bioassessment protocols for use in streams and rivers: periphyton, benthic macroinvertebrates, and fish. EPA 841-D-97-002, Office of Water, USEPA, Washington, DC

Waters TF (1983) Replacement of brook trout by brown trout over 15 years in a Minnesota stream: production and abundance. Trans Am Fish Soc 112:137-146

Appendix 1 List of species that were found in the base survey or DFO survey, and ecological preferences for each species (from Halliwell et al. 1998, Jennings et al. 1998, Smoger \& Angermeier 1998).

\begin{tabular}{|c|c|c|c|c|c|c|}
\hline $\begin{array}{l}\text { Family and } \\
\text { Spawning } \\
\text { Common Name }\end{array}$ & Origin & Tolerance & Feeding & Habitat & Temperature & \\
\hline \multicolumn{7}{|l|}{ Petromyzontidae } \\
\hline \multicolumn{7}{|l|}{ Anguillidae } \\
\hline \multicolumn{6}{|l|}{ Salmonidae } & $\mathrm{O}$ \\
\hline brook trout & $\mathrm{N}$ & I & $\mathrm{TC}$ & WC & $\mathrm{C}$ & SL \\
\hline Atlantic salmon & $\mathrm{N}$ & I & $\mathrm{TC}$ & WC & $\mathrm{C}$ & $\mathrm{SL}$ \\
\hline brown trout & E & M & $\mathrm{TC}$ & WC & C & SL \\
\hline \multicolumn{7}{|l|}{ Cyprinidae } \\
\hline lake chub & $\mathrm{N}$ & $M$ & GF & WC & C & SL \\
\hline creek chub & $\mathrm{N}$ & $\mathrm{T}$ & GF & WC & C-W & $\mathrm{O}$ \\
\hline golden shiner & $\mathrm{N}$ & $\mathrm{T}$ & GF & WC & W & $\mathrm{O}$ \\
\hline common shiner & $\mathrm{N}$ & $M$ & GF & WC & C-W & $\mathrm{SL}$ \\
\hline blacknose dace & $\mathrm{N}$ & $\mathrm{T}$ & GF & WC & C-W & SL \\
\hline $\begin{array}{l}\text { Catostomidae } \\
\text { white sucker }\end{array}$ & $\mathrm{N}$ & T & GF & B & C-W & $\mathrm{O}$ \\
\hline $\begin{array}{l}\text { Ictaluridae } \\
\text { brown bullhead }\end{array}$ & $\mathrm{N}$ & T & GF & B & W & $\mathrm{O}$ \\
\hline $\begin{array}{l}\text { Gasterosteidae } \\
\text { three-spine stickleback }\end{array}$ & k N & M & IN & WC & C-W & $\mathrm{O}$ \\
\hline
\end{tabular}

Origin

Tolerance

Feeding

Habitat

Temperature

Spawning
$\mathrm{N}$ : native species, E: exotic species

$\mathrm{T}$ : tolerant species, I: intolerant species, $\mathrm{M}$ : intermediate tolerance PF: parasite feeding, TC: top carnivores, GF: general feeders, IN: insectivores $\mathrm{W}$ : water column species, B: benthic species C: coldwater species, W: warmwater species, C-W: coolwater species SL: simple lithophilic spawners, O: others 
Appendix 2 ISCS scores for all sites in the base survey and the DFO survey, and their narrative interpretation of stream conditions. Narrative conditions are based on ISCS scores (refer to Table 5).

\begin{tabular}{|c|c|c|c|c|c|c|c|c|c|}
\hline \multirow[t]{2}{*}{ Site number } & \multicolumn{5}{|c|}{ Individual score of ISCS metrics } & \multirow{2}{*}{$\begin{array}{l}\text { Total } \\
\text { ISCS } \\
\text { Score }\end{array}$} & \multirow{2}{*}{$\begin{array}{l}\text { Narrative } \\
\text { Condition }\end{array}$} & \multirow{2}{*}{$\begin{array}{c}\text { Habitat } \\
\text { Quality } \\
\text { Score }\end{array}$} & \multirow{2}{*}{$\begin{array}{l}\text { Water } \\
\text { Temp. }\end{array}$} \\
\hline & $\begin{array}{c}\# \\
\text { Species }\end{array}$ & $\begin{array}{c}\% \\
\text { Salmo }\end{array}$ & $\begin{array}{c}\% \\
\text { Brook }\end{array}$ & $\begin{array}{c}\% \\
\text { Sucker }\end{array}$ & $\begin{array}{l}\% \\
\text { CS }\end{array}$ & & & & \\
\hline \multicolumn{10}{|l|}{ Base survey } \\
\hline site 1 & 5 & 0 & 10 & 10 & 0 & 25 & Fair & 135 & $17^{\circ} \mathrm{C}$ \\
\hline site 2 & 10 & 10 & 5 & 10 & 5 & 40 & Good & 172 & $13^{\circ} \mathrm{C}$ \\
\hline site 3 & 10 & 10 & 10 & 10 & 10 & 50 & Excellent & 178 & $14^{\circ} \mathrm{C}$ \\
\hline site 4 & 10 & 10 & 0 & 10 & 5 & 35 & Good & 115 & $17^{\circ} \mathrm{C}$ \\
\hline site 5 & 10 & 10 & 5 & 10 & 5 & 40 & Good & 155 & $16^{\circ} \mathrm{C}$ \\
\hline site 6 & 10 & 10 & 0 & 10 & 10 & 40 & Good & 125 & $16^{\circ} \mathrm{C}$ \\
\hline site 7 & 10 & 10 & 5 & 10 & 10 & 45 & Excellent & 162 & $15^{\circ} \mathrm{C}$ \\
\hline site 8 & 10 & 10 & 10 & 10 & 5 & 45 & Excellent & 165 & $13^{\circ} \mathrm{C}$ \\
\hline site 9 & 10 & 10 & 10 & 10 & 10 & 50 & Excellent & 155 & $11^{\circ} \mathrm{C}$ \\
\hline site 10 & 0 & 0 & 0 & 0 & 0 & 0 & Very poor & 95 & $24^{\circ} \mathrm{C}$ \\
\hline \multicolumn{10}{|l|}{ DFO survey } \\
\hline site $11(00)$ & 5 & 5 & 0 & 10 & 0 & 20 & Fair & 149 & $12.7^{\circ} \mathrm{C}$ \\
\hline site 11 (99) & 5 & 5 & 0 & 10 & 0 & 20 & Fair & 149 & $19.7^{\circ} \mathrm{C}$ \\
\hline site 11 (98) & 5 & 5 & 0 & 10 & 5 & 25 & Fair & 149 & $14^{\circ} \mathrm{C}$ \\
\hline site 11 (97) & 10 & 10 & 0 & 10 & 0 & 30 & Good & 149 & $19^{\circ} \mathrm{C}$ \\
\hline site 11 (95) & 10 & 5 & 0 & 10 & 0 & 25 & Fair & 149 & $11^{\circ} \mathrm{C}$ \\
\hline site 11 (86) & 5 & 5 & 0 & 10 & $\mathrm{~N} / \mathrm{A}$ & $\mathrm{N} / \mathrm{A}$ & $\mathrm{N} / \mathrm{A}$ & 149 & $16^{\circ} \mathrm{C}$ \\
\hline site 12 (99) & 5 & 5 & 5 & 10 & 5 & 30 & Good & 155 & $11.6^{\circ} \mathrm{C}$ \\
\hline site 12 (95) & 10 & 10 & 10 & 10 & 5 & 45 & Excellent & 155 & $9^{\circ} \mathrm{C}$ \\
\hline site 13 (80) & 5 & 0 & 0 & 10 & 0 & 15 & Poor & 126 & $17^{\circ} \mathrm{C}$ \\
\hline site 14 (86) & 5 & 10 & 0 & 10 & 0 & 25 & Fair & 115 & $16.5^{\circ} \mathrm{C}$ \\
\hline site $15(00)$ & 5 & 0 & 0 & 0 & 5 & 10 & Poor & 115 & $13.7^{\circ} \mathrm{C}$ \\
\hline site 15 (99) & 5 & 5 & 0 & 5 & 5 & 20 & Fair & 108 & $15.8^{\circ} \mathrm{C}$ \\
\hline
\end{tabular}

